\title{
Outcome of the use of $0.9 \%$ saline versus $0.45 \%$ saline for fluid rehydration in moderate and severe diabetic ketoacidosis in children
}

Nora El Said Badawi ${ }^{1}$, Mona Hafez ${ }^{1}$, Heba Sharaf Eldin² ${ }^{2}$, Hend Mehawed Abdelatif ${ }^{1}$, Shimaa Atef ${ }^{1}$, Mohamed Mohamed Ismail ${ }^{1}$ and Noha Arafa ${ }^{1 *}$ (D)

\begin{abstract}
Background: The debate for the optimum sodium concentration in the rehydration solution in diabetic ketoacidosis (DKA) persists till the moment. The aim was to compare the outcome of $0.9 \%$ saline versus $0.45 \%$ saline in children with moderate and severe (DKA) regarding the effect on serum electrolytes, duration of DKA resolution and the incidence of hyperchloremia.

Results: A retrospective analysis of 121 children with moderate or severe DKA was done. After the initial $4 \mathrm{~h}$ in which both groups received normal saline, patients were divided into two groups continuing on $0.9 \%(N=72)$ or switched to $0.45 \%$ saline $(N=49)$. Serum chloride and $\mathrm{Cl} / \mathrm{Na}$ ratios were significantly higher in $0.9 \%$ saline group at 4 and $8 \mathrm{~h}$. The $0.9 \%$ saline group had significantly higher proportion of hyperchloremia at 4 and $8 \mathrm{~h}$ ( $P$ value: 0.002 , 0.02). The median duration of correction of DKA ( $14 \mathrm{~h}$ among $0.9 \%$ saline versus $10 \mathrm{~h}$ among $0.45 \%$ saline) without significant difference $(P$ value $=0.43$ ). The change in plasma glucose, effective osmolarity, corrected Na levels were comparable between groups.

Conclusion: There is an unavoidable iatrogenically induced rise in serum chloride with higher incidence of hyperchloremia with the use of normal saline in rehydration of children presenting in DKA and shock. The use of $0.45 \%$ saline as post-bolus rehydration fluid is not associated with a decline in the corrected serum sodium concentration and does not affect the rate of correction of acidosis or rate of drop in blood glucose or duration of DKA resolution when compared to normal saline.
\end{abstract}

Keywords: DKA, Hyperchloremia, $0.45 \%$ saline, Normal saline, Rehydration

\section{Background}

Diabetic ketoacidosis (DKA) is an earnest acute complication of type one diabetes which can occur at any age, often can occur at the onset of disease or in the already diagnosed patients due to discontinuation of insulin or improper sick day management [1]. The goal of all

\footnotetext{
* Correspondence: Noha.Hussein@kasralainy.edu.eg

'The Diabetes Endocrine, Metabolism Pediatric Unit (DEMPU), Children's Hospital, Kasralainy, Faculty of Medicine, Cairo University, Rasheedy Street, Sayeda Zeinab, Cairo 11562, Egypt

Full list of author information is available at the end of the article
}

existing DKA management protocols to do instantaneous fluid replacement to correct the intracellular dehydration and the ongoing electrolytes losses [2]. The fluid replacement must be prompt but very careful to avoid the cerebral edema [3]. Cerebral edema is known to be the leading cause of death in diabetic ketoacidosis (DKA) and the treatment centers around avoiding this complication of management [4]. Argument is still present regarding the type, amount, and rate of intravenous (IV) replacement fluid therapy. International Society for Pediatric and Adolescent Diabetes (ISPAD), 2018

\section{Springer Open}

(c) The Author(s). 2021 Open Access This article is licensed under a Creative Commons Attribution 4.0 International License, which permits use, sharing, adaptation, distribution and reproduction in any medium or format, as long as you give appropriate credit to the original author(s) and the source, provide a link to the Creative Commons licence, and indicate if changes were made. The images or other third party material in this article are included in the article's Creative Commons licence, unless indicated otherwise in a credit line to the material. If material is not included in the article's Creative Commons licence and your intended use is not permitted by statutory regulation or exceeds the permitted use, you will need to obtain permission directly from the copyright holder. To view a copy of this licence, visit http://creativecommons.org/licenses/by/4.0/. 
consensus guidelines advise that after the initial resuscitation, fluids used may be in the form of solution with tonicity ranging between 0.45 and $0.9 \%$ according to the clinical evaluation of the patients [2], but till now based on the present evidence there is no particular treatment strategy preferable than the other [5].

The rationale for the use of half NS is to minimize the risk of cerebral edema through declined rise in corrected serum sodium and drop in effective serum osmolality [6].

The normal saline $(0.9 \%)$ is the most appropriate physiological solution used for the initial rehydration however it carries the risk of increasing the chloride load which results in development of hyperchloremic metabolic acidosis [7]. Hyperchloremic metabolic acidosis (DKA) may be observed during management and is caused either by urinary loss of bicarbonate precursors as ketones and/or iatrogenically from chloride administration in rehydration fluids [8]. The acidifying effect of chloride was blamed in masking the resolution of DKA [9]. With the shortage of availability of costly laboratory investigations (such as $\beta$-hydroxybutyrate) in many developing countries identifying the cause of protracted metabolic acidosis in DKA patients is not always feasible. In the current study we aimed to compare the outcome of using 2 different concentrations of sodium in the rehydration fluids ( $0.9 \%$ NS versus $0.45 \%$ saline) in moderate and severe DKA with regards to the effect on serum electrolytes, effective osmolarity, duration of DKA resolution, the incidence of hyperchloremia.

\section{Methods}

\section{Participants}

This is a retrospective cohort study included 49 children 1-15years with moderate or severe DKA who received rehydration solution using $0.45 \%$ saline at intermediate care unit of Diabetes, Endocrine, and Metabolism Pediatric Unit (DEMPU), Children's Hospital over the period from August to October 2016. This was compared to historical cohort of 72 patients with moderate and severe DKA who received $0.9 \%$ saline as rehydration solution at the same unit during the preceding period from March to July 2016.

DKA was defined as having blood glucose $>200 \mathrm{mg} / \mathrm{dL}$ $(11.4 \mathrm{mmol} / \mathrm{L})$, a venous $\mathrm{pH}<7.30$ or a plasma bicarbonate level $<15 \mathrm{mmol} / \mathrm{L}$, and ketonemia or ketonuria and arterial blood gases (ABG) showed moderate DKA if arterial $\mathrm{pH}>7.1$ and $<7.2$ with bicarbonate $<10$ and $>5 \mathrm{mmol} / \mathrm{L}$ or severe DKA if arterial $\mathrm{pH}<7.1$, bicarbonate $<5 \mathrm{mmol} / \mathrm{L}$ [10]. Patients were excluded if they had (1) any neurological abnormality or Glasgow Coma Scale $(\mathrm{GCS})<13$, (2) received any therapy (HCO3, mannitol, fluid, insulin) before admission to our hospital or were referred after the first $4 \mathrm{~h}$ of management, (3) any cause of acidosis other than DKA, (4) corrected serum sodium $\leq 130$ and $\geq 150 \mathrm{mmol} / \mathrm{l}$.

Data on age, sex, onset of diabetes whether newly diagnosed or known, duration of diabetes, precipitating factor for DKA development, duration of insulin infusion, dose of insulin infusion, volume of fluid infused, and the use of bicarbonate therapy were collected.

All patients included in the study were managed according to ISPAD guidelines for DKA treatment [2] which is the protocol adopted at our unit which allow consistency concerning treatment. The protocol adopted at our unit as follows:

All included patients were managed accordingly: immediate measurement of blood glucose and capillary $\mathrm{BHOH}$ using glucometer (Free style Optium, Abbott) ${ }^{1}$ were performed when available, weighing the patient and assessment of level of consciousness according to Glasgow Coma Scale [11] and severity of dehydration, full examination for a precipitating factor, and laboratory investigations

Subsequent clinical and biochemical monitoring included hourly assessment of vital signs, hourly (or more frequently as indicated) neurological observations (GCS) for warning signs and symptoms of cerebral edema, hourly capillary blood glucose concentrations, measurement of serum glucose, $\mathrm{Na}, \mathrm{K}, \mathrm{CL}, \mathrm{BUN}$, creatinine, and blood gases at the time of admission and every $4 \mathrm{~h}$ till DKA resolution. N.B. Blood glucose was measured in $\mathrm{mg} / \mathrm{dl}$, where $1 \mathrm{mg} / \mathrm{dl}=18 \mathrm{mmol} / \mathrm{L}$.

- Calculation of:

- Anion Gap using the following formula: $(\mathrm{Na}+)-(\mathrm{HCO} 3-+\mathrm{Cl}-)$. Normal $=12 \pm 2 \mathrm{mmol} / \mathrm{L}$

- Corrected $\mathrm{Na}=$ Measured $\mathrm{Na}+2$ (blood glucose $-100) / 100$

- Serum osmolality (mosmol/kg); effective: $2(\mathrm{Na})+$ glucose/18 [12].

- Hyperchloremia is defined as ratio of chloride: sodium $[\mathrm{Cl}-: \mathrm{Na}+]>0.79[13]$.

- Fluid therapy

A. Resuscitation fluid ( $0.9 \%$ saline) was used for restoration of the peripheral circulation. The volume administered is $10 \mathrm{ml} / \mathrm{kg}$ over $1-2 \mathrm{~h}$, this bolus fluid is given to patients with severe volume depletion and may be repeated until tissue perfusion is adequate. However, shocked patients with impaired peripheral perfusion were given $20 \mathrm{ml} / \mathrm{kg}$ as rapidly as possible.

${ }^{1}$ Abbott House, Vanwall Business Park, Vanwall Road, Maidenhead, Berkshire SL6 4XE, UK. 
B. Deficit replacement fluid therapy: First $4 \mathrm{~h}$ $0.9 \%$ saline was used then fluid with tonicity either $0.45 \%$ saline (half NS) or $0.9 \%$ saline was used.

C. Patients were divided into two groups according to the type of rehydration fluid used after $4 \mathrm{~h}$ : group 1 ( $N=72)$ : Rehydration solution using $0.9 \%$ saline; group $2(N=49)$ : Rehydration solution using $0.45 \%$ saline provided that those patients had normal Na concentration.

The volume of total fluid replacement therapy and its rate were calculated based on data from Darrow study [2, 14].

D. Glucose $10 \%$ was added to replacement fluids (ratio 1:1) when plasma glucose reached approximately $300 \mathrm{mg} / \mathrm{dL}$ or if the rate of blood glucose dropped very rapidly $(>88 \mathrm{mg} / \mathrm{dL} / \mathrm{h}$ ) after initial fluid expansion.

E. Potassium replacement was initiated after measurement of its serum level at concentration of $40 \mathrm{meq} / \mathrm{L}$ after initial volume expansion and concurrent with starting insulin therapy. If the patient was hyperkalemic, potassium replacement therapy was postponed until urine output was documented.

F. Bicarbonate therapy was considered in cases of severe acidosis $(\mathrm{PH}<6.9)$ with life threatening cardiac decompensation and also indicated in cases of life threatening hyperkalemia. It is given intravenously at a dose of $1-2 \mathrm{meq} / \mathrm{kg}$ over $1 \mathrm{~h}$.

G. Cerebral edema: monitoring of clinical symptoms and signs suggestive of development of cerebral edema (headache, deterioration of neurological status, development of any neurological deficit, convulsion, Cushing's triad) is a crucial part of DKA management. Once clinically suspected, immediate management is initiated. The rate of rehydration fluid is adjusted to maintain good perfusion and normal blood pressure while avoiding overhydration. Hypertonic solution (mannitol or hypertonic saline) is given slowly over 10$15 \mathrm{~min}$. Other measures to decrease intracranial pressure must be applied (elevation of the head $30^{\circ}$, intubation with hyperventilation if patient had severe deterioration of neurologic status).

\section{- Insulin therapy}

Insulin infusion was started after $1 \mathrm{~h}$ of initiation of volume expansion by fluid replacement therapy at a dose ranging from $0.05 \mathrm{U}$ to $0.1 \mathrm{U} / \mathrm{kg} / \mathrm{h}$. Criteria for shifting to subcutaneous insulin included resolution of acidosis $(\mathrm{PH} \geq 7.3, \mathrm{HCO} 3 \geq 15 \mathrm{mEq} / \mathrm{L})$, a good general condition and hemodynamic stability, tolerating oral intake, patient no longer on vasopressors and $\mathrm{BOHB}<3 \mathrm{mmol} / \mathrm{L}$.

The study protocol received approval from our Institutional Research Ethics Committee.

\section{Statistical analysis}

Data were statistically described in terms of mean \pm standard deviation $( \pm \mathrm{SD})$, median and range for numerical variables or frequencies, and percentages for categorical variables. Comparison of numerical variables between the study groups was done using Student's $T$ test. For comparing categorical data, chi-square $\left(\chi^{2}\right)$ test was performed. Exact test was used instead when the expected frequency is less than 5. $P$ values less than 0.05 was considered statistically significant. All statistical calculations were done using IBM SPSS (Statistical Package for the Social Science; IBM Corp, Armonk, NY, USA) release 22 for Microsoft Windows.

\section{Results}

The total number of included patients was 121 participants. They were divided into two groups according to the type of rehydration fluid used after 4 h: group 1 (0.9\% saline) included 72 participants and group 2 ( $0.45 \%$ saline) included 49 participants. Clinical characteristics and initial biochemical parameters at admission are illustrated in Table 1.

Our patients were 65 females $(53.7 \%)$ and 56 males (46.3\%), their ages ranging from 1 to 14 years and all patients were neurologically free with GCS $>13$. The patients were divided according to the degree of dehydration at presentation into moderate dehydration 27 patients $(22.3 \%)$ and severe dehydration 94 patients (77.7\%). Of the whole group, 55 patients were known to have diabetes (45.5\%) while for 66 patients (54.5\%) DKA was their first presentation. Concerning the severity of DKA, 49 patients had moderate DKA while 72 patients had severe DKA. Corrected sodium levels of our patients at presentation and after $4 \mathrm{~h}$ (at time of change of fluid) ranged from 135 to $\leq 150$ and their ABG correlated with the criteria of moderate and severe DKA. $\mathrm{BHOH}$ at presentation ranged from 3.1-8.3 $\mathrm{mmol} / \mathrm{L}$. The duration of correction of ketoacidosis among the whole group ranged from 6 to $40 \mathrm{~h}$.

The age of participants of both groups was comparable, the median age of normal saline NS (group 1) was 8 years (range, 1-13) while that of group 2 (half normal saline) was 7 years $(1-14) P$ value $=1.000$. The number (\%) of patients in NS group who had new onset T1DM was $47 / 72$ (58.3\%) compared to $24 / 49$ (49\%) in the other group, the difference was not significant $P$ value $=0.59$. 
Table 1 Demographic and baseline biochemical variables at time of admission

\begin{tabular}{|c|c|c|c|}
\hline Parameters & $\begin{array}{l}\text { Group } 1(0.9 \%) \\
(N=72)\end{array}$ & $\begin{array}{l}\text { Group } 2(0.45 \%) \\
(N=49)\end{array}$ & $P$ value \\
\hline Age (years) (mean $\pm S D$ ) & $7.11 \pm 3.77$ & $7.39 \pm 3.87$ & 0.69 \\
\hline \multicolumn{4}{|l|}{$\begin{array}{l}\text { Sex } \\
n(\%)\end{array}$} \\
\hline Male & $39(45.8 \%)$ & 17 (34.7\%) & \multirow[t]{2}{*}{0.03} \\
\hline Female & $33(54.2 \%)$ & $32(65.3 \%)$ & \\
\hline \multicolumn{4}{|l|}{$\begin{array}{l}\text { Degree of dehydration } \\
n(\%)\end{array}$} \\
\hline Moderate & $17(23.6 \%)$ & $10(20.4 \%)$ & \multirow[t]{2}{*}{0.43} \\
\hline Severe & $55(76.4 \%)$ & $39(79.6 \%)$ & \\
\hline \multicolumn{4}{|l|}{$\begin{array}{l}\text { DKA presentation } \\
n(\%)\end{array}$} \\
\hline Newly diagnosed & $42(41.7 \%)$ & $24(51 \%)$ & \multirow[t]{2}{*}{0.59} \\
\hline Known to have diabetes & $30(58.3 \%)$ & $25(49 \%)$ & \\
\hline \multicolumn{4}{|l|}{$\begin{array}{l}\text { Shock therapy }(\mathrm{ml} / \mathrm{kg}) \\
n(\%)\end{array}$} \\
\hline No & $15(20.8 \%)$ & $25(51 \%)$ & \multirow[t]{4}{*}{0.001} \\
\hline $10 \mathrm{ml} / \mathrm{kg}$ & $15(20.8 \%)$ & $3(6.1 \%)$ & \\
\hline $20 \mathrm{ml} / \mathrm{kg}$ & $19(26.4 \%)$ & $4(8.2 \%)$ & \\
\hline $30 \mathrm{ml} / \mathrm{kg}$ & $23(31.9 \%)$ & 17 (34.7\%) & \\
\hline $\begin{array}{l}\text { Rate of fluids (maintenance }+ \text { deficit) } \\
\mathrm{ml} / \mathbf{k g} / \mathbf{h} \text { (mean } \pm \mathrm{SD} \text { ) }\end{array}$ & $99.93 \pm 26.88$ & $94.16 \pm 31.13$ & 0.34 \\
\hline Actual fluid intake $(\mathrm{L})$ (median) & 4.73 & 4.45 & 0.39 \\
\hline Patients received bicarbonate therapy & $13(18.1 \%)$ & $11(22.4 \%)$ & 0.36 \\
\hline \multicolumn{4}{|l|}{$\begin{array}{l}\text { Mean insulin dose }(I \mathrm{U} / \mathrm{kg} / \mathrm{h}) \\
\text { mean } \pm S D\end{array}$} \\
\hline $1 \mathrm{st} 6 \mathrm{~h}$ & $0.11 \pm 0.02$ & $0.1 \pm 0.01$ & 0.80 \\
\hline After 1 st $6 \mathrm{~h}$ & $0.11 \pm 0.03$ & $0.1 \pm 0.02$ & 0.48 \\
\hline Duration of DKA resolution (hours) (median, range) & $14(6-40)$ & $10(6-38)$ & 0.43 \\
\hline Glucose $(\mathrm{mg} / \mathrm{dl})($ mean $\pm \mathrm{SD})$ & $532.67 \pm 157$ & $550.14 \pm 139.64$ & 0.53 \\
\hline Serum $\mathrm{Na}(\mathrm{meq} / \mathrm{L})($ mean $\pm \mathrm{SD})$ & $133.58 \pm 4.56$ & $134.16 \pm 4.24$ & 0.47 \\
\hline Corrected $\mathrm{Na}($ meq/L) $($ mean $\pm \mathrm{SD})$ & $142.4 \pm 4.54$ & $143.12 \pm 4.75$ & 0.40 \\
\hline Serum $\mathrm{CL}($ meq/L) $($ mean $\pm \mathrm{SD})$ & $102.67 \pm 5.02$ & $102.91 \pm 4.49$ & 0.81 \\
\hline CL:Na ratio (mean $\pm \mathrm{SD}$ ) & $0.77 \pm 0.03$ & $0.77 \pm 0.18$ & 0.97 \\
\hline BHOB (mmol/L) (mean \pm SD) & $5.44 \pm 1.13$ & $5.43 \pm 1.55$ & 0.95 \\
\hline $\mathbf{P H}($ mean $\pm \mathrm{SD})$ & $7.08 \pm 0.099$ & $7.06 \pm 0.12$ & 0.39 \\
\hline HCO3 (meq/L) (mean \pm SD) & $5.8 \pm 2.5$ & $6 \pm 2.7$ & 0.65 \\
\hline Anion gap (mean $\pm S D$ ) & $25.9 \pm 4.4$ & $24.6 \pm 3.5$ & 0.12 \\
\hline Creatinine $(\mathrm{mg} / \mathrm{dl})($ mean $\pm \mathrm{SD})$ & $0.75 \pm 0.24$ & $0.76 \pm 0.31$ & 0.81 \\
\hline $\begin{array}{l}\text { Effective osmolality (mosmol/L) } \\
(\text { mean } \pm \mathrm{SD})\end{array}$ & $297.1 \pm 11.9$ & $300.9 \pm 11.3$ & 0.07 \\
\hline \multicolumn{4}{|l|}{$\begin{array}{l}\text { Severity of DKA } \\
n(\%)\end{array}$} \\
\hline Moderate $(n=49)$ & $29(40.3 \%)$ & $20(40.8 \%)$ & \multirow[t]{2}{*}{0.95} \\
\hline Severe $(n=72)$ & $43(59.7 \%)$ & $29(59.2 \%)$ & \\
\hline
\end{tabular}


Precipitating factors for DKA were similar in both groups with infections representing $46.7 \%$ in NS group and $44 \%$ in $0.45 \%$ saline. There was no discernible precipitant in $46.7 \%$ of NS group and none in $52 \%$ of the other group.

Significantly more patients in the NS group needed shock therapy $(79.2 \%$ versus $49 \%$ in 0.45 saline group, $P=0.001$ ). Rates of fluids, total fluid intake, severity of DKA, mean insulin doses/hour, and number of patients needing sodium bicarbonate were comparable (Table 1).

The initial laboratory data at the time of recruitment (serum glucose, corrected serum $\mathrm{Na}$, serum $\mathrm{Cl}, \mathrm{Cl}: \mathrm{Na}$ ratio, $\mathrm{PH}, \mathrm{HCO} 3$, creatinine, effective osmolarity, and anion gap) were comparable between two groups (Table 1). Corrected serum sodium was comparable in both groups throughout the study period. Serum chloride and $\mathrm{Cl} / \mathrm{Na}$ ratios were significantly higher in NS group at 4 and $8 \mathrm{~h}$ after initiation of therapy. Serum chloride levels rose significantly by $2.1 \mathrm{mmol} / \mathrm{L}$ between hour 4 and hour 8 in NS group $(P=0.007)$ and by $1.7 \mathrm{mmol} / \mathrm{L}$ in $0.45 \%$ group $(P=0.37)$. The NS group (I) had significantly higher proportion of hyperchloremia at 4 and $8 \mathrm{~h}$ ( $P$ value, $0.002,0.02$ respectively). On the other hand, the anion gap was significantly higher at 4 and $8 \mathrm{~h}$ in $0.45 \%$ saline-receiving patients with ( $P$ values, $0.006,0.000$ respectively). At the start, $\mathrm{BHOH}$ levels in both groups had a mean value of $5.5 \pm 1.1$ vs $5.4 \pm$ 1.5 ( $P$ value $=1.000)$. Differences continued to be insignificant throughout the study period (Table 2). Concerning the course of blood glucose during correction, there was no significant difference between two groups at 4 and $8 \mathrm{~h}$ ( $P$ value $=0.45,1.00$ respectively). Effective serum osmolarity was comparable during the study period. Figures 1, 2, 3 and 4 show blood chloride, glucose, anion gap, and bicarbonate trends in the two groups throughout the study period.

Table 2 The course of $\mathrm{PH}, \mathrm{HCO}$, corrected $\mathrm{Na}, \mathrm{CL}, \mathrm{Cl}: \mathrm{Na}$ ratio, capillary BHOB, anion gap, glucose, and effective osmolarity at 4 and 8 h among both groups

\begin{tabular}{|c|c|c|c|c|}
\hline Laboratory variables & Timing (hours) & $\begin{array}{l}\text { Group } 1 \\
0.9 \% \text { NS } \\
(N=72) \\
\text { Mean } \pm \text { SD }\end{array}$ & $\begin{array}{l}\text { Group2 } \\
0.45 \% \text { NS }(N=49) \\
\text { Mean } \pm \text { SD }\end{array}$ & $P$ value \\
\hline \multirow[t]{3}{*}{$\mathrm{PH}$} & 4 & $7.16 \pm 0.1$ & $7.14 \pm 0.13$ & 0.37 \\
\hline & 8 & $7.23 \pm 0.09$ & $7.20 \pm 0.1$ & 0.55 \\
\hline & At recovery & $7.35 \pm 0.04$ & $7.36 \pm 0.05$ & 0.21 \\
\hline \multirow[t]{3}{*}{ HCO3 (meq/L) } & 4 & $7.34 \pm 3.4$ & $6.98 \pm 3.18$ & 0.56 \\
\hline & 8 & $9.8 \pm 3.6$ & $8.8 \pm 3.5$ & 0.5 \\
\hline & At recovery & $16.9 \pm 1.37$ & $17.02 \pm 1.96$ & 0.82 \\
\hline \multirow[t]{3}{*}{ Serum Na (meq/L) } & 4 & $136.28 \pm 4.94$ & $135.94 \pm 4.64$ & 0.70 \\
\hline & 8 & $137.3 \pm 5.4$ & $138.4 \pm 6.6$ & 0.98 \\
\hline & At recovery & $140.7 \pm 6.5$ & $140.3 \pm 5.4$ & 0.69 \\
\hline \multirow[t]{3}{*}{ Corrected $\mathrm{Na}(\mathrm{meq} / \mathrm{L})$} & 4 & $142 \pm 4.8$ & $143.1 \pm 4.6$ & 0.18 \\
\hline & 8 & $141 \pm 6$ & $143.4 \pm 6.2$ & 0.12 \\
\hline & At recovery & $140.7 \pm 6.5$ & $140.3 \pm 5.4$ & 0.69 \\
\hline \multirow[t]{2}{*}{$\mathrm{CL}$ (meq/L) } & 4 & $106.28 \pm 5.1$ & $103 \pm 3.6$ & 0.002 \\
\hline & 8 & $108.4 \pm 5.6$ & $104.7 \pm 6.1$ & 0.06 \\
\hline \multirow[t]{2}{*}{ CL:Na ratio } & 4 & $0.78 \pm 0.03$ & $0.76 \pm 0.02$ & 0.001 \\
\hline & 8 & $0.79 \pm 0.02$ & $0.76 \pm 0.03$ & 0.000 \\
\hline \multirow[t]{2}{*}{ Anion gap } & 4 & $22.8 \pm 5.1$ & $26.1 \pm 5$ & 0.002 \\
\hline & 8 & $18.5 \pm 4.5$ & $25.8 \pm 5.6$ & 0.000 \\
\hline \multirow[t]{2}{*}{$\mathrm{BHOH}$} & 4 & $4.6 \pm 1.1$ & $4.9 \pm 1.5$ & 0.97 \\
\hline & 8 & $4.05 \pm 1.1$ & $4.09 \pm 1.4$ & 0.88 \\
\hline \multirow[t]{2}{*}{ Plasma glucose (mg/dl) } & 4 & $389 \pm 166$ & $433 \pm 145$ & 0.35 \\
\hline & 8 & $307.3 \pm 134$ & $324.8 \pm 124.5$ & 0.51 \\
\hline \multirow[t]{2}{*}{ Effective serum osmolality (mosmol/L) } & 4 & $293 \pm 12.4$ & $296 \pm 12.7$ & 0.21 \\
\hline & 8 & $291 \pm 12.5$ & $295 \pm 13$ & 0.22 \\
\hline \multirow{3}{*}{$\begin{array}{l}\text { Hyperchloremia } \\
n(\%)\end{array}$} & 0 & $9(15.3 \%)$ & $4(11.1 \%)$ & 0.4 \\
\hline & 4 & $16(28.6 \%)$ & $2(4.9 \%)$ & 0.002 \\
\hline & 8 & 15 (34.9\%) & $4(12.5 \%)$ & 0.02 \\
\hline
\end{tabular}




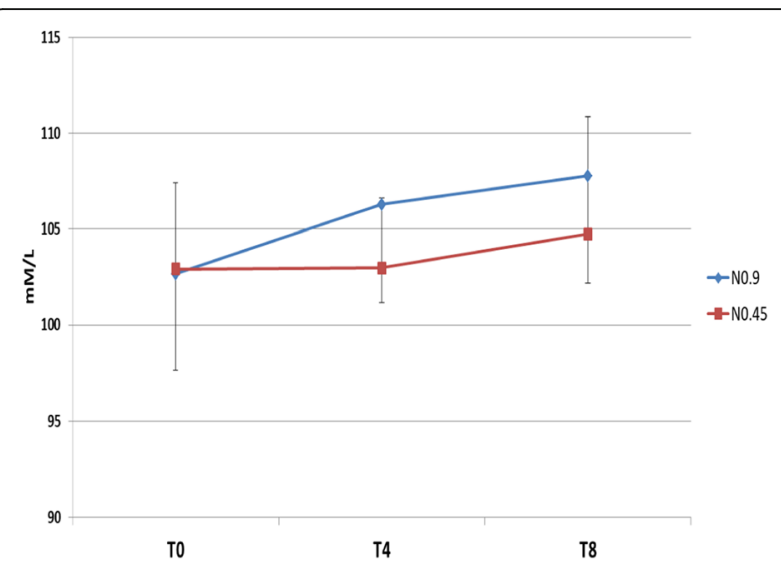

Fig. 1 Mean $\pm S D$ of serum chloride ( $\mathrm{mmol} / \mathrm{L}$ ) in NS 0.9 and saline 0.45 groups over the study period

Although the median duration of correction of ketoacidosis was longer among normal saline group than $0.45 \%$ saline ( 14 versus $10 \mathrm{~h}$ ), it did not reach statistically significant difference $(P$ value $=0.43)$. None of recruited patients developed brain edema or renal dysfunction. All recruited patients were discharged without any alteration in their neurological status compared to the previous status before DKA development.

Comparison between patients who did not receive any shock therapy in both groups $(0.9 \%$ versus $0.45 \%$ ) was shown in Table 3 . The comparison revealed statistically significant difference between both groups regarding CL:Na ratio and anion gap at $8 \mathrm{~h}$ $(P$ values, $0.007,000)$ respectively. However, the other compared parameters did not show significant difference.

\section{Discussion}

The management of DKA should be aimed at restoration of normal homeostasis and tissue perfusion with a gradual reduction of acidosis and blood glucose to avoid possible complications. Isotonic (normal saline NS) is the fluid most commonly used for resuscitation initiation of rehydration during DKA management in pediatric and adult guidelines. Recently, however, there has been increasing awareness that the nonphysiological nature can lead to hyperchloremic metabolic acidosis and acute renal injury as a result of renal vasoconstriction [15]. Other investigators have not found a detrimental effect of NS on overall mortality or renal functions [16]. The debate for replacing NS by other solutions with different $\mathrm{Na}$ concentrations persists till the moment. In our study, we compared the use of two solutions in the rehydration of children with moderate and severe DKA (NS which contains $\mathrm{Na} 154 \mathrm{meq} / \mathrm{L})$ and $(0.45 \% \mathrm{NS}$ which contains $\mathrm{Na} 75 \mathrm{meq} / \mathrm{L}$ ).

In the current study, the serum bicarbonate level and $\mathrm{PH}$ were comparable between both groups at the time of start of management and throughout the study with no significant difference between both groups. This is in agreement to what reported by Savas-Erdeve et al. that the use of an isotonic solution did not create a difference in $\mathrm{HCO} 3$ or PH levels when compared to hypotonic solution with lower Na concentration [3].

The primary cause of acidemia in DKA is thought to be ketoacidosis, lactic acidosis, and renal dysfunction can be contributing factors [13]. Hyperchloremia predominates instead in the recovery phase. Misinterpretation of hyperchloremic acidosis may obscure the detection of ketoacidosis resolution [8]. A simple bedside test with detection of $\mathrm{BOHB}$ levels can solve the

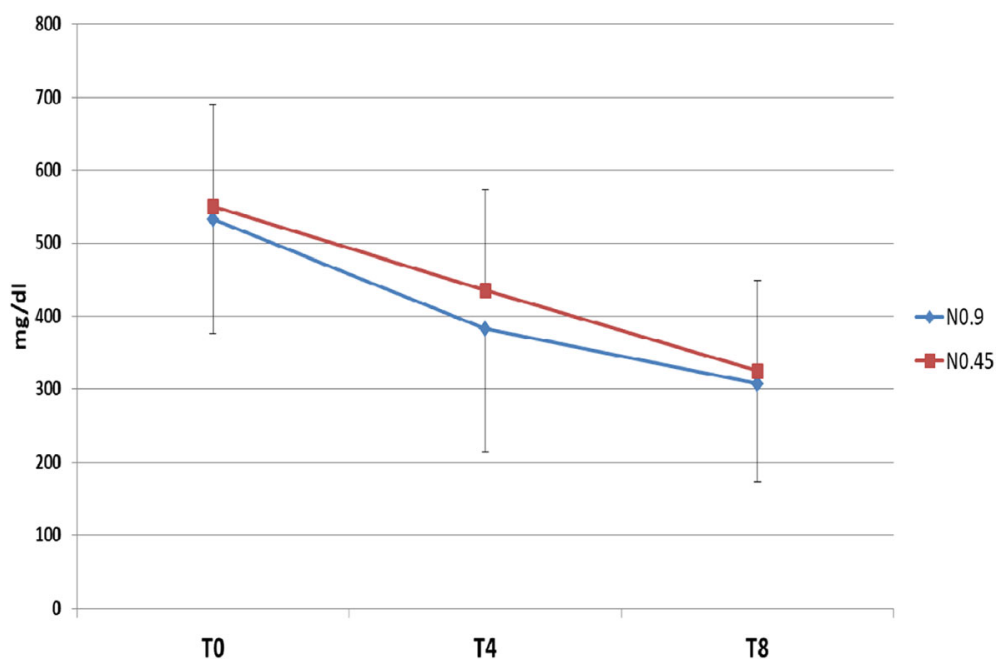

Fig. 2 Mean \pm SD of serum glucose $(\mathrm{mg} / \mathrm{dl})$ in NS 0.9 and saline 0.45 groups 


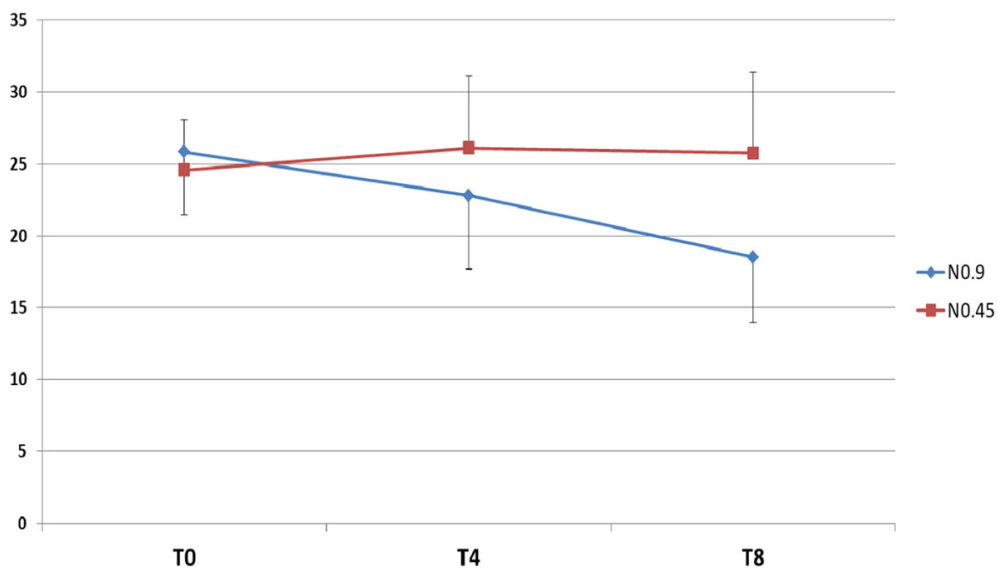

Fig. 3 Mean \pm SD of anion gap in NS 0.9 and saline 0.45 groups over the study period

problem, unfortunately this test is not always available in limited resource settings. Although both groups of patients in our study presented with comparable chloride levels (102.7 vs $102.9 \mathrm{mmol} / \mathrm{L})$ on admission, differences became evident as early as $4 \mathrm{~h}$ into the study when both groups had been receiving NS and before rehydration fluids for the second group were changed (106.3 vs $103 \mathrm{mmol} / \mathrm{L}$ ). It is important to note that more patients in group 1 had received anti-shock treatment with NS boluses $(79.2 \%$ vs $49 \%)$ and this had already impacted on their serum chloride levels. Additionally, comparison between patients who did not receive any shock therapy in both groups $(0.9 \%$ versus $0.45 \%)$ revealed no significant difference regarding chloride levels. Previous studies have found the highest chloride levels to occur with periods of rapid rehydration with large amounts of normal saline [17]. However, anti-shock treatment can be lifesaving in some situations for restoring perfusion and improving glomerular filtration.
Eight hours into the study ( $4 \mathrm{~h}$ after group 2 had been switched $0.45 \%$ saline) serum chloride levels had climbed a further $2.1 \mathrm{mmol} / \mathrm{L}$ in group 1 and $1.7 \mathrm{mmol} / \mathrm{L}$ in group $2(108.4$ vs $104.7 \mathrm{mmol} / \mathrm{L})$. The NS group had significantly higher proportion of patients with hyperchloremia at 4 and $8 \mathrm{~h}$. Concerning the chloride, sodium ratio, the NS group had significantly higher ratio at 4 and $8 \mathrm{~h}$ than those in the $0.45 \%$ saline group. In contrast, such frequency of patients with hyperchloremia was not seen in the $0.45 \%$ NS group which suggests that the choice of rehydration fluid might be an important factor for the development of hyperchloremia. This comes in line with several studies that showed that patients who received normal saline had significantly higher incidence of hyperchloremic acidosis [18-20].

The median duration of management till DKA resolution was longer among the group of NS (14 h) versus (10 h) among $0.45 \%$ saline group but it did not reach statistical significance $(P$ value $=0.43)$. We speculate that

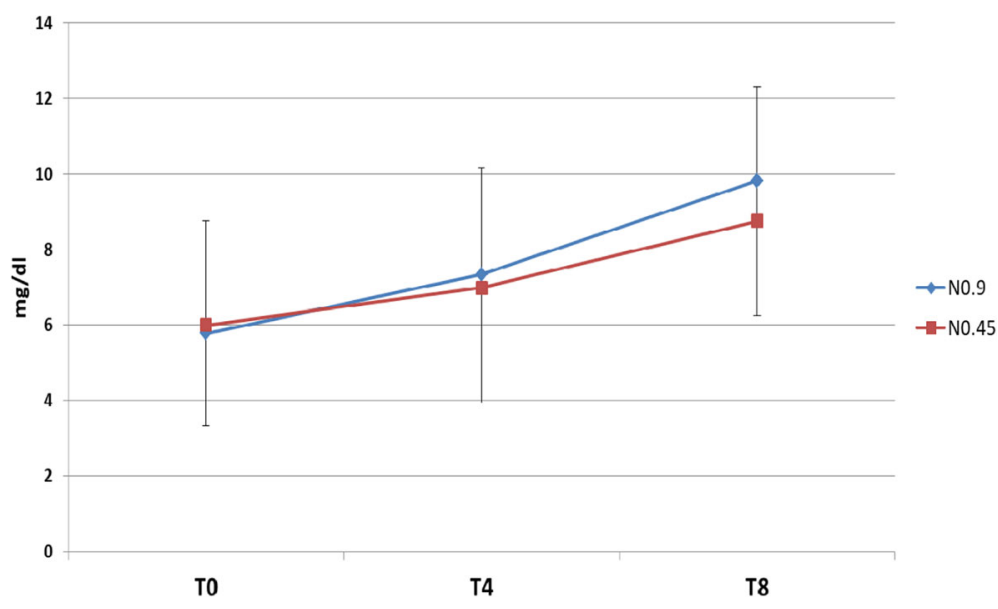

Fig. 4 Serum $\mathrm{HCO} 3(\mathrm{mmol} / \mathrm{L})$ in NS 0.9 and saline 0.45 groups over the study period 
Table 3 Comparison between patients who did not receive shock therapy in both groups (0.9\% versus $0.45 \%$ saline) regarding different laboratory parameters

\begin{tabular}{|c|c|c|c|c|}
\hline Laboratory variables & Timing (hours) & $\begin{array}{l}\text { Group } 1 \\
0.9 \% \text { NS } \\
(N=15) \\
\text { Mean } \pm \text { SD }\end{array}$ & $\begin{array}{l}\text { Group2 } \\
0.45 \% \text { NS }(N=25) \\
\text { Mean } \pm \text { SD }\end{array}$ & $P$ value \\
\hline \multirow[t]{4}{*}{ PH } & 0 & $7.14 \pm 0.07$ & $7.13 \pm 0.06$ & 0.60 \\
\hline & 4 & $7.21 \pm 0.09$ & $7.22 \pm 0.05$ & 0.62 \\
\hline & 8 & $7.29 \pm 0.09$ & $7.26 \pm 0.04$ & 0.42 \\
\hline & 12 & $7.32 \pm 0.04$ & $7.34 \pm 0.04$ & 0.56 \\
\hline \multirow[t]{4}{*}{ HCO3 (meq/L) } & 0 & $8.4 \pm 1.6$ & $8.02 \pm 1.8$ & 0.49 \\
\hline & 4 & $10.05 \pm 2.8$ & $9.41 \pm 2.1$ & 0.42 \\
\hline & 8 & $13.3 \pm 3.01$ & $11.4 \pm 1.9$ & 0.07 \\
\hline & 12 & $13.25 \pm 2.8$ & $12.6 \pm 1.3$ & 0.67 \\
\hline \multirow[t]{3}{*}{ Serum Na (meq/L) } & 0 & $133.8 \pm 3.8$ & $134 \pm 4.2$ & 0.85 \\
\hline & 4 & $136.3 \pm 5.7$ & $135.4 \pm 5.3$ & 0.62 \\
\hline & 8 & $136.3 \pm 4.6$ & $136.3 \pm 6.6$ & 0.98 \\
\hline \multirow[t]{3}{*}{ Corrected $\mathrm{Na}$ (meq/L) } & 0 & $141.8 \pm 4.7$ & $142 \pm 4.6$ & 0.91 \\
\hline & 4 & $140.8 \pm 5.2$ & $142.3 \pm 5.1$ & 0.37 \\
\hline & 8 & $141.1 \pm 6.1$ & $136.3 \pm 4.6$ & 0.40 \\
\hline \multirow[t]{3}{*}{ CL (meq/L) } & 0 & $102.4 \pm 4.9$ & $102.7 \pm 4.3$ & 0.86 \\
\hline & 4 & $104.7 \pm 3.8$ & $102.6 \pm 3.5$ & 0.12 \\
\hline & 8 & $107.6 \pm 4.8$ & $103.6 \pm 4.2$ & 0.08 \\
\hline \multirow[t]{3}{*}{ CL:Na ratio } & 0 & $0.77 \pm 0.03$ & $0.76 \pm 0.02$ & 0.94 \\
\hline & 4 & $0.76 \pm 0.01$ & $0.75 \pm 0.02$ & 0.21 \\
\hline & 8 & $0.79 \pm 0.01$ & $0.76 \pm 0.03$ & 0.007 \\
\hline \multirow[t]{3}{*}{ Anion gap } & 0 & $23.6 \pm 2.9$ & $22.8 \pm 2.9$ & 0.48 \\
\hline & 4 & $21.4 \pm 5.02$ & $23.7 \pm 4.03$ & 0.16 \\
\hline & 8 & $13.8 \pm 2.03$ & $11.4 \pm 1.9$ & 0.000 \\
\hline \multirow[t]{3}{*}{$\mathrm{BHOH}$} & 0 & $4.8 \pm 0.94$ & $5.32 \pm 1.6$ & 0.26 \\
\hline & 4 & $3.9 \pm 1.1$ & $4.2 \pm 1.3$ & 0.48 \\
\hline & 8 & $3.07 \pm 0.88$ & $3.4 \pm 1$ & 0.43 \\
\hline \multirow{3}{*}{$\begin{array}{l}\text { Hyperchloremia } \\
n(\%)\end{array}$} & 0 & 2 (13.3\%) & $2(8 \%)$ & 0.63 \\
\hline & 4 & $2(13.3 \%)$ & $1(4 \%)$ & 0.22 \\
\hline & 8 & $2(13.3)$ & $2(8 \%)$ & 0.63 \\
\hline \multicolumn{2}{|c|}{ Duration of DKA resolution (hours) } & $9.87 \pm 3.58$ & $8.80 \pm 3.317$ & 0.34 \\
\hline
\end{tabular}

the prolonged duration of insulin infusion among normal saline group due to misinterpretation of hyperchloremic acidosis as ongoing ketoacidosis but unfortunately lack of availability of chloride levels after 8 $\mathrm{h}$ was a limitation in this study.

Basnet et al. found hyponatremia to be induced in patients receiving $0.45 \%$ from the start of DKA management. This did not occur in patients switching to $0.45 \%$ after an initial period of NS treatment [18]. Our findings concur with those of that study since we found no significant differences in serum sodium levels between the two groups throughout the course of DKA management.
This is also in line with Rother et al. who found that rehydration using $75 \mathrm{mmol} / \mathrm{L}$ of $\mathrm{Na}$ did not lead to decline in the serum $\mathrm{Na}$ level [21]. However, this contradicts Toledo et al. who reported a higher plasma Na level with the use of an isotonic perfusate than that achieved with a perfusate with a lower $\mathrm{Na}$ content [22]. Savas-Erdeve et al. did not find any difference in plasma $\mathrm{Na}$ and plasma corrected $\mathrm{Na}$ between patients who received rehydration solutions containing $75 \mathrm{mEq} / \mathrm{L}$ and patients received $100 \mathrm{mEq} / \mathrm{L}$ of $\mathrm{Na}$. Gosmanov et al. recommend in adult DKA management that if patients are to be switched to $0.45 \%$ saline after an initial 4-h resuscitation 
with NS, patients must be both hemodynamically stable and have a normal to high corrected serum sodium level. If patients subsequently become hyponatremic, treatment should revert to NS [23].

Concerning the course of glycemia, the initial glucose level and its rate of decline did not show any significant differences between the two studied groups. This is noted also in other studies using rehydration solutions with different $\mathrm{Na}$ concentrations [3, $18,20]$. In addition, there was no significant difference between the two studied groups as regards the rate of insulin infusion. This is in line with what was reported by Yung et al. [20]. This denotes that insulin infusion dose is not affected by the change in $\mathrm{Na}$ concentration in the rehydration fluids during DKA management.

Capillary $\mathrm{BHOH}$ levels did not differ between the two groups throughout the study period but the anion gap dropped faster in the group receiving NS, significantly lower levels being demonstrable as early as $4 \mathrm{~h}$ into the management of DKA. It is speculated that since $\mathrm{BHOH}$ levels were equal in both groups throughout, it was the higher levels of serum chloride in the NS patients that narrowed the gap in this group.

\section{Limitations of the study}

The retrospective nature of the study is the main limitation. Future prospective studies with larger number of participants with more emphasis on determination of brain injuries associated with DKA management and its risk factors are needed.

\section{Conclusion}

There is an unavoidable iatrogenically induced rise in serum chloride with the use of normal saline in the initial resuscitation of children presenting in DKA and shock. The incidence of hyperchloremia is significantly less with the use of half normal saline. Half normal saline is not associated with a decline in the corrected serum sodium concentration and does not affect the rate of correction of acidosis or rate of drop in blood glucose or duration of DKA resolution when compared to normal saline solution as post-bolus rehydration fluid therapy in pediatric patients with DKA.

\footnotetext{
Abbreviations

DKA: Diabetic ketoacidosis; IV: Intravenous; ISPAD: International Society for Pediatric and Adolescent Diabetes; DEMPU: Diabetes, Endocrine, and Metabolism Pediatric Unit; GCS: Glasgow Coma Scale; ABG: Arterial blood gases; $\mathrm{BHOH}$ : $\beta$-Hydroxybutyrate; NS: Normal saline
}

\section{Authors' contributions}

Dr. MH shared in study design, interpretation of data, statistical analysis, drafting and writing manuscript, and final revision of the version to be published. Dr. NB revised the results and participated in writing the manuscript, Dr. HSE did the laboratory work up, Dr. MI was the consultant who directly oversaw the progress of the cases, Drs. HM and SA shared in design of study, data collection, interpretation of data, drafting of the article, and final revision for publication. Dr. NA participated in data collection and sorting for statistical analysis, drafting of the article, writing the manuscript, and final revision for publication. All authors have read and approved the manuscript.

\section{Funding}

Not applicable.

Availability of data and materials

Data is available with the authors on request.

\section{Declarations}

Ethics approval and consent to participate

Received approval from Research Ethics Committee of Kasr Alainy, Faculty of Medicine, Cairo University (number: 1:141014); consent to participate was not applicable.

\section{Consent for publication}

Not applicable.

\section{Competing interests}

All authors declare no conflict of interest.

\section{Author details}

'The Diabetes Endocrine, Metabolism Pediatric Unit (DEMPU), Children's Hospital, Kasralainy, Faculty of Medicine, Cairo University, Rasheedy Street, Sayeda Zeinab, Cairo 11562, Egypt. ²Department of Clinical and Chemical Pathology, Cairo University, Cairo, Egypt.

Received: 25 September 2020 Accepted: 4 March 2021

Published online: 01 April 2021

\section{References}

1. Ronsley R, Islam N, Ronsley C, Metzger DL, Panagiotopoulos C (2018) Adherence to a pediatric diabetic ketoacidosis protocol in children presenting to a tertiary care hospital. Pediatr Diabetes 19(2):333-338. https://doi.org/10.1111/pedi.12556

2. Wolfsdorf Jl, Glaser N, Agus M, Fritsch M, Hanas R, Rewers A et al (2018) ISPAD Clinical Practice Consensus Guidelines 2018: diabetic ketoacidosis and the hyperglycemic hyperosmolar state. Pediatr Diabetes 19(27):155-177. https://doi.org/10.1111/pedi.12701

3. Savaş-Erdeve \$̧, Berberoğlu M, Oygar P, Şıklar Z, Kendirli T, Hacıhamdioğlu B et al (2011) Efficiency of fluid treatments with different sodium concentration in children with type 1 diabetic ketoacidosis. J Clin Res Pediatr Endocrinol 3(3):149-153. https://doi.org/10.4274/jcrpe.v3i3.29

4. Bohn D, Daneman D (2002) Diabetic ketoacidosis and cerebral edema. Curr Opin Pediatr 14(3):287-291. https://doi.org/10.1097/00008480-2002 06000-00001

5. Kuppermann N, Ghetti S, Schunk JE, Stoner MJ, Rewers A, McManem et al (2018) Clinical trial of fluid infusion rates for pediatric diabetic ketoacidosis. N Engl J Med 378(24):2275-2287. https://doi.org/10.1056/NEJMoa1716816

6. Glaser N, Barnett P, McCaslin I, Nelson D, Trainor J, Louie J, Pediatric Emergency Medicine Collaborative Research Committee of the American Academy of Pediatrics et al (2001) Risk factors for cerebral edema in children with diabetic keotacidosis. N Engl J Med 344(4):264-269. https:// doi.org/10.1056/NEJM200101253440404

7. Dunger DB, Sperling MA, Acerini $C L$, Bohn GJ, Daneman D, Dane TP et al (2004) European Society for Paediatric Endocrinology/Lawson Wilkins Paediatric Endocrine Society consensus statement on diabetic ketoacidosis in children and adolescents. Paediatrics 113:133-140

8. Taylor D, Durward A, Tibby SM, Thorburn K, Holton F, Johnstone IC et al (2006) The influence of hyperchloraemia on acid base interpretation in 
diabetic ketoacidosis. Intensive Care Med 32(2):295-301. https://doi.org/10.1 007/s00134-005-0009-1

9. Olivieri L, Chasm R (2013) Diabetic ketoacidosis in the pediatric emergency department. Emerg Med Clin N Am 31(3):755-773. https://doi.org/10.1016/j. emc.2013.05.004

10. Chase HP, Garg SK, Jelley DH (1990) Diabetic ketoacidosis in children and the role of outpatient management. Pediatr Rev 11(10):297-304. https://doi. org/10.1542/pir.11-10-297

11. Teasdale G, Jennett B (1974) Assessment of coma and impaired consciousness. A practical scale. Lancet 2(7872):81-84. https://doi.org/10.101 6/s0140-6736(74)91639-0

12. Halperin ML, Goldstein MB (1999) Fluid, electrolyte, and acid-base physiology, 3rd edn. Saunders, Philadelphia

13. Durward A, Skellett S, Mayer A, Taylor D, Tibby SM, Murdoch IA (2001) The value of the chloride: sodium ratio in differentiating the etiology of metabolic acidosis. Intensive Care Med 27(5):828-835. https://doi.org/10.1 007/s001340100915

14. Darrow DC (1959) The physiologic basis for estimating requirements for parenteral fluids. Pediatr Clin N Am 6(1):29-41. https://doi.org/10.1016/ S0031-3955(16)30758-1

15. Yunos NM, Bellomo R, Hegarty C, Story D, Ho L, Bailey M (2012) Association between a chloride-liberal vs chloride-restrictive intravenous fluid administration strategy and kidney injury in critically ill adults. JAMA 308(15): 1566-1572. https://doi.org/10.1001/jama.2012.13356

16. Abbas Q, UI Ain N, Ehsan L, Saleem K, Jamil M, UI Haque A (2017) Hyperchloremia and its association with outcomes in critically ill children. SM Emerg Med Criti Care 1(4):1018

17. Van Zyl D, Rheeder P, Delport E (2012) Fluid management in diabeticacidosis-Ringer's lactate versus normal saline: a randomized controlled trial. Q J Med 105:337-343

18. Basnet S, Venepalli PK, Andoh J, Verhulst S, Koirala J (2014) Effect of normal saline and half normal saline on serum electrolytes during recovery phase of diabetic ketoacidosis. J Intensive Care Med 29(1):38-42. https://doi.org/1 $0.1177 / 0885066612467149$

19. Chua HR, Venkatesh B, Stachowski E, Schneider AG, Perkins K, Ladanyi S et al (2012) Plasma-Lyte 148 vs $0.9 \%$ saline for fluid resuscitation in diabetic ketoacidosis. J Crit Care 27(2):138-145. https://doi.org/10.1016/j. jcrc.2012.01.007

20. Yung M, Letton G, Keeley S (2017) Controlled trial of Hartmann's solution versus $0.9 \%$ saline for diabetic ketoacidosis. J Paediatr Child Health 53(1):1217. https://doi.org/10.1111/jpc.13436

21. Rother Kl, Schwenk WF 2nd. (1994) Effect of rehydration fluid with 75 $\mathrm{mmol} / \mathrm{L}$ of sodium on serum sodium concentration and serum osmolality in young patients with diabetic ketoacidosis. Mayo Clin Proc 69(12):11491153. https://doi.org/10.1016/S0025-6196(12)65766-8

22. Toledo JD, Modesto V, Peinador M, Alvarez P, López-Prats JL, Sanchis R et al (2009) Sodium concentration in rehydration fluids for children with ketoacidotic diabetes: effect on serum sodium concentration. J Pediatr 154(6):895-900. https://doi.org/10.1016/j.jpeds.2008.12.042

23. Gosmanov AR, Gosmanova EO, Dillard-Cannon E (2014) Management of adult diabetic ketoacidosis. Diabetes Metab Syndr Obes 7:225-264

\section{Publisher's Note}

Springer Nature remains neutral with regard to jurisdictional claims in published maps and institutional affiliations.

\section{Submit your manuscript to a SpringerOpen ${ }^{\circ}$ journal and benefit from:}

- Convenient online submission

- Rigorous peer review

- Open access: articles freely available online

High visibility within the field

- Retaining the copyright to your article

Submit your next manuscript at $\boldsymbol{\nabla}$ springeropen.com 